\title{
死に対する恐怖は, 健康への近道か？ 一存在論的脅威が健康行動に及ぼす影響に関する実験的検討一
}

\author{
$\bigcirc$ 富塚澄江 ${ }^{1}$. 藤 桂 $^{2}$, \\ ( ${ }^{1}$ 千葉産業保健総合支援センター 2 筑波大学 人間系) \\ キーワード : 死への恐怖, 健康行動, 存在劦威管理理論
}

\begin{abstract}
Does the fear toward death promote healthy life? ; The experimental examination of the influence of the mortality salience on the health behavior. Sumie Tomizuka ${ }^{1}$, Kei Fuji ${ }^{2}$

( ${ }^{1}$ Chiba Occupational Health Promotion Center $\quad{ }^{2}$ University of Tsukuba)
\end{abstract} Key Words: Fear toward death, Health behaviors, Terror management theory

\section{問題と目的}

現行の保健指導においては,「死亡率」「死の 4 重奏」など の “死”という文言を用いて，危機感を喚起するような場面 が散見される。しかし，この“死”という文言を使用するこ とは健康行動にどのような影響を及ぼしているのであろうか この点に関して, 存在劦威管理理論に関する研究 (Goldenberg, Arndt, Hart，\& Brown，2005）では，課題を通 して死という概念に直面（存在論的驾威が顕在化）した条件 において不健康的な食行動が抑制されたことが示されている 国内でも，30～50 代の社会人を対象に web 調査を行った富 塚・藤（2015）が，日常生活における存在論的劦威は，それ らを緩衝する要素である文化的世界観への同化・自尊感情の 向上・関係性の確保（Hart, Shaver, \& Goldenberg, 2005) への希求を経て, 健康行動が促進されることを明らかにして いる。そして死への恐怖に直面し, 緩衝要素を希求するプロ セスを媒介することで健康行動は促進されるが，死を回避す るだけでは，健康行動に結び付かないことを示している。

本研究ではこれらの研究結果に基づき，実際の保健指導場 面を模した実験を行う。その際, 死への恐怖を喚起しつつも, 緩衝要素が喚起されない場合には, 健康行動の実行に対する 積極的姿勢はむしろ抑制されると予測する。さらに，死に対 する恐怖は, 直後よりも一定時間が経過した後で高くなり得 る (Arndt, Greenberg, Solomon, Pyszczynski, \& Simon, 1997) ことを踏まえ，時間経過による健康行動への影響を検討する 目的で，保健指導 2 週間後時点での測定も併せて行う。

\section{方 法}

実験参加者 初回保健指導時の参加者数は, 29 名（存在劦威 条件 13 名, 存在劦威緩衝条件 16 名）であった。また, 2 週 間後時点での参加者数は, 25 名 (平均 44.96 歳, $S D=8.23$; 存在劦威条件 11 名, 存在劦威緩衝条件 14 名）であった。 実験計画 健康行動案に関しては, 1 要因参加者間計画（存 在驾威 vs 存在劦威緩衝）での分析を行った。また健康行動又 テージ (Prochaska \& Diclemente, 1983) に関しては，保健指 導の条件（存在驾威 vs 存在妿威緩衝） $\times$ 時期（1回目 or 2 回目）の 2 要因混合計画での分析を行った。

測定内容・実験手続き 実験参加者を無作為に 2 群（存在驾 威条件，存在驾威緩衝条件）に分け，メールインタビューと いうカバーストーリーにて保健指導を行い, 反応を測定した。 初回のメールで, 存在劦威条件においては, 死への恐怖を 強調するような特定保健指導の導入的文章のみを提示した。 一方，存在劦威緩衝条件には，同じ文章を提示しつつ, Hart et al.（2005）が提唱した存在論的劦威を緩衝し得る三つの 要素（文化的世界観への同化, 自尊感情の向上, 関係性の確 保）への希求を動機づけるような文章を加えて提示した。そ の後, いずれの条件でも, 生活習慣改善のための行動の例を 示した上で,「今日から, どのような行動を実施したいと思う か」について尋ね, 自由記述形式にて行動案の記入を求めた。 また，その回答として挙げられた行動案の個数を計数すると
ともに, 回答のうち, インタビューイーが提示した例とは異 なる案を, 回答者が自らの生活に即し独自に考えたアイディ アであるオリジナル行動案と位置づけ, その個数を計数した。

2 週間後, 再度メールを送信し,「前回から今までに生活習 慣改善行動が実施されていたか」について尋ね, いない場合 にはその理由などについて詳細に尋ねた。初回と 2 週間後の 健康行動の実施状況や, 実施および非実施理由に関する回答 内容を参照し, Prochaska \& Diclemente（1983）が示した健 康行動のステージ (無関心期, 関心期, 準備期, 行動期, 維 持期）のいずれのステージに相当するかを，心理学を専攻す る大学院生 1 名と大学教員 1 名の合議を基に判断した。

\section{結 果}

生活習慣改善行動の発案に及ぼす影響 初回時に挙げられた, 行動案数 (29名) について, 条件間で $t$ 検定を行ったが有意 差は見られなかった $(t(23.59)=0.41, n . s ., d=.16)$ 。しかし, 行 動案数に含まれるオリジナル行動案数, および全行動案数に 占めるその割合を算出し, これらを従属変数として分析した ところ有意差が見られた $(t(24.76)=2.07, p<.05, d=.73 ; t(26.94)=$ $2.81, p<.01, d=1.02)$ 。すなわち, 存在劦威条件では, 生活習慣 改善のための行動案を存在务威緩衝条件と同程度挙げていた ものの, その一方で, 自らの生活に合わせた独自の生活習慣 改善行動を考案しようとしなくなっていたことが示された。 健康行動のステージ変化に及ぼす影響 健康行動のステージ を従属変数 (25 名) として条件 $\times$ 時期の 2 要因混合計画を行 つた結果（Figure 1)，交互作用が有意であった $(F(1,23)=4.68$, $p<.05, \eta_{\mathrm{p}}{ }^{2}=.17$ )。単純主効果検定(Bonferroni 法)を行った結果, 存在劦威条件においてのみ, 初回と 2 週間後の間で有意差が 認められた $(p<.05)$ 。すなわち, 存在劦威条件でのみ, 健康行 動のステージの後退が生じていたことが明らかになった。

\section{考察}

存在驾威条件では存在驾威緩衝条件と比べ，独自に考えた オリジナル行動案数が少なく, また 2 週間後の健康行動への 関心の低下が著しくなっていた。すなわち, 死に対する恐怖

（存在論的劦威）が喚起されるのみで, Hart et al. (2005) が示したような緩衝要素への動機づけがなされていない状況 では，むしろ健康行動が阻害される可能性が示唆された。

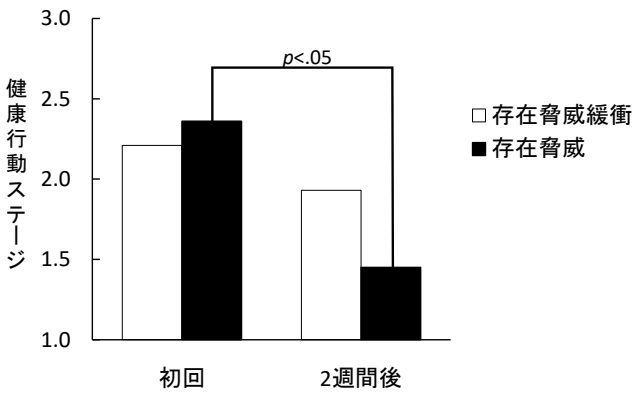

Figure 1. 健康行動ステージの変化. 